\title{
ACADEMIC STRESS AND ACADEMIC MOTIVATION AMONG UNDERGRADUATE STUDENTS OF KEBBI STATE UNIVERSITY OF SCIENCE AND TECHNOLOGY, ALIERO KEBBI STATE, NIGERIA
}

\author{
${ }^{*}$ Shehu Haruna Muza, ${ }^{2}$ Sagir Muhammad and ${ }^{3}$ Haruna Sani Aliero, Ph.D \\ ${ }^{1 \& 3}$ Department of Education \\ Kebbi State University of Science and Technology, Aliero Nigeria \\ P.O. Box 1144, Aliero, Kebbi state, Nigeria \\ E-mail: muzask38@gmail.com Tel: +234 7034907238 \\ ${ }^{2}$ Department of Science Education \\ Kebbi State University of Science and Technology, Aliero Nigeria \\ P.O. Box 1144, Aliero, Kebbi state, Nigeria \\ Tel: +2348069779705 E-mail: sagiraliero@gmail.com
}

\begin{abstract}
The study assessed the relationship between academic stress and academic motivation among UG 2 students of Kebbi state university of science and technology, Aliero Kebbi state, Nigeria. The study employed correlational design and was guided by two (2) hypotheses. Findings revealed that significant relationship exist between Academic stress and intrinsic motivation among UG 2 students $r=0.706$, significant relationship also exist between Academic stress and extrinsic motivation $r=0.632$. The following recommendations were made: Seminars, workshops and conferences should be organized for all stakeholders in educational sector to know that academic stress is hazardous to the wellbeing of the students; therefore, university should review its policies, goals and objectives to meet the needs and aspirations of students in order to minimize their academic stress. Teachers, parents and counsellors should educate students on how to cope with academic stress and understand the adverse effect of academic stress.
\end{abstract}

Keywords: Academic stress, Academic motivation, Undergraduate and Science. 


\section{Introduction}

Academic stress is the most common emotional and mental state that students experience during their studies. Academic stress according to Hashin (2003) refers to academic pressure the school poses to students. Academic related stress have included fear of failing behind the course work, finding motivation to study, time pressures and concern about academic ability.

Altback (2007) academic stress is student perception of school as exerting great influence over their lives and feels that they live in a state of substantial powerlessness. Academic stress could also be informed of difficulty of achieving social intimacy due to excessive studies. If for this reason, students lack time and opportunity to develop interpersonal relationships, such students are said to be experiencing academic stress (Allensworth, E., \& Easton, J.Q, 2007). According to Abdulraheem (2013), academic stress refers to facing such tasks that produce tension such as preliminary exams semester system, fear of academic failure. Also students' reaction to school challenges; for some tertiary institution is stressful because it is an abrupt change from secondary school. For others, separation from home is a source of stress.

Motivation is defined as the absence of intent or drive (Jangho, 2012). Motivation is one of the three key determinants of performance as described by Ivancevitch, Konopaske and Matteson (2005), with the other two determinants being capacity to perform and opportunity to perform. They asserted that motivation is made up of three distinct components which are direction, intensity and persistence. They described direction as relating to what an individual chooses to do when presented with a number of alternatives, intensity as the strength of the response once the choice is made and persistence as to how long the response is maintained. Student who is under stress display several differences compared with those who are not stressed, and several factors were significantly correlated with stress levels (Misra, 2000).

Many studies deal with students' motivation regarding their learning aspirations and their psychological processes of learning (Murton, 2008; Paulsen \& Feldman, 2005; Valle, 2003; Salili, 2001; Bures, 2000). Nevertheless, learning motivation is not to be confused with academic motivation for the latter focuses exclusively on reasons why individuals decide for and continue with university studies.

Craigmitchell (2008) opined that there is a relationship between stress and motivation and agreed that they are in fact two side of the same coin. In his opinion, Craigmitchell submitted that the link between stress and motivation is presented to conclude that not all stress is bad. Moreover, if the effects of stress are known prior and the levels are controlled to an optimum, it is possible to produce high levels of motivation.

On the whole, Jangho (2012) noted that academic stress may be influenced by an interaction among motivation, school grades, depression and personality. Therefore, strategies to reduce academic pressures should take into consideration the importance of those factors. Increasing motivation may occur through interventions against stress and depression. Moreover, appropriate stress management may help students to become more motivated.

Conversely, the consequence may leave the person a prolonged emotional disturbance. University provides students' tertiary education and psychosocial development. Besides, 
pursuing knowledge in University, a student also gets too socialized with different kinds of people and undergoes psychological development. Studies show that entering University may bring strain or stress (Gall, Evans, \& Bellerose, 2000). This is because University students face changing education system, lifestyle, and social environment. University students need to reach certain levels of academic achievement to graduate.

However, a review of the literature indicates that very few researches have been done in Nigerian context and that is also limited to undergraduate students of Federal university of technology, Minna and NCE students of Federal College of Education (Tech), Gusau, Zamfara State, Nigeria. Therefore, it is highly important to conduct a similar study to examine the situation in Kebbi state university of science and technology, Aliero Nigeria

\section{Statement of the Problem}

University is a social institution where learning takes place. However, the transition of individual students from different secondary schools, to tertiary institution may come with a lot of anxiety, stress and difficulties. University Education face challenges in terms of academic motivation and expectation from teachers, personal academic interaction with new colleagues, method of teaching, new academic institution, security challenges and many others that can create excessive pressure which may in turn have effect on student academic motivation.

In addition, sitting for examination is stressful because of the pressure to review all the learned materials within a giving period of time which leads students to feel unfamiliar situations and most of the University students find it difficult to achieve a balance between continuous assessment test and examination. The instability of these emotions easily initiates unusual behaviours which may affect their learning ability and academic stress.

It is also observed that stress management technique are very poor and ineffective in the University, It is on the basis of this that the researcher investigated the Relationship between Academic Stress and Academic Motivation among undergraduate students of Kebbi state university of science And technology, Aliero Nigeria.

\section{Objectives of the Study}

For the purpose of this study, the following objectives are stated; to determine

1. The relationship between Academic stress and intrinsic motivation among UG 2 students

2. The relationship between Academic stress and extrinsic motivation among UG 2 students

\section{Hypotheses}

The following hypotheses guided the study:

1. There is no significant relationship between Academic stress and intrinsic motivation among UG 2 students 
Journal DOI: 10.46654/ij.24889849

2. There is no significant relationship between Academic stress and extrinsic motivation among UG 2 students

\section{Significance of the Study}

This study will expose teachers to understand how academic stress can hamper the efforts of students to achieve academically at the university level. It will help teachers pay special attention to the academically stressed students so that they can be able to regulate learning environment for better academic motivation. It will also help parents to understand what they should do to minimize academic stress among their children at home and in the school.

\section{Methodology}

\section{Research design}

The study employed correlational design. Correlational design according to McMilla and Schumacher (2010) is research design in which information on at least two variable are collected in order to investigate the relationship between the variables.

\section{Population and sampling technique}

The population of this study is the entire UG 2 students from the (5) five faculties which are 2,064, the sample of this study are three hundred and twenty two (322) UG 2 students of the university. The sample was selected in conformity with Krejcie and Morgan (1970). Stratified proportionate random sampling technique was used in the selection of sample from the various faculties. It's also to ensure a proper representation of the entire population. The sample size of 322 UG 2 Students was drawn from Faculty of Agriculture, Faculty of Education, Faculty of Engineering, Faculty of Life Science and Faculty of Physical Science.

Table 1. Distribution of the UG 2 Population Sample and Percentage across Faculties

\begin{tabular}{lccc}
\hline S/No Faculties & Population & Sample & $\begin{array}{c}\text { Percentage } \\
(\boldsymbol{\%})\end{array}$ \\
\hline 1. Faculty of Agriculture & 448 & 70 & 22 \\
2. Faculty of Education & 319 & 50 & 16 \\
3. Faculty of Engineering & 206 & 32 & 10 \\
4. Faculty of Life Science & 380 & 59 & 18 \\
5. Faculty of Physical Science & 711 & 111 & 34 \\
Total & $\mathbf{2 , 0 6 4}$ & $\mathbf{3 2 2}$ & $\mathbf{1 0 0}$ \\
\hline
\end{tabular}

\section{Instrumentation}

Two main instruments were used for this study are adopted. The instruments are Academic Stress Scale and Academic Motivation Scale. Academic Stress instrument was developed by Balarabe (2004). It comprised of two Sections. Section A, Biographic Data, and Section B Academic Motivation Scale which was developed by Heater (1981). The instrument has two sections, A \& B. 


\section{Biographical Data}

This section consists of 5 items which seek to determine the demographic information of the respondent involved in the study. These, include Name of School, Gender, Age, Course of Study and Department.

\section{Academic Stress Scale}

This instrument was adopted to measure academic stress of Students and it has reliability coefficient .877. It has 20 items which represented the students' feelings.

\section{Scoring guide for Academic Stress Scale}

$<29$ - low stressful

30 - 59 - averagely stressful

60 - 100 highly stressful

The Scale consists of 20 items that measures the characteristics of Academic Stress.

The Scale is on 4-point Likert scale ranging from 3 (Very True), 2 (True), 1 (Untrue) and 0 (Very Untrue).

Therefore, the highest scores of Academic Stress among respondents will be (60 3x20 Items), while the lowest possible Academic Stress scores of the respondents will be (0x20 items)

\section{Academic Motivation Scale}

This instrument is standardized one that seeks to determine aspect of academic motivation of students and it has reliability coefficient of .892. It has 20 items scale. It has five points scale ranging from strongly agreed (SA), Agreed (A), Not Sure (NS), Disagreed (D), Strongly Disagreed (SD) which represent students' feelings.

\section{Scoring guide for Academic Motivation Scale (AMS)}

$<29$ - low academic motivation

30 - 59 averagely academic motivation

60 - 100 highly academic motivation

The Scale consist of 20 items that measure the characteristic of Academic Motivation.

The Scale is on a 5 - point Likert Scale ranging from 5 (Strong Agree), 4 (Agree), 3 (Not Sure), 2 (Disagree) and 1 (Strongly Disagree).

Therefore, the highest possible Academic motivation Scores a respondent will get in the Scale is (60 - 100 5x20), while the lowest possible Academic Motivation Scores a respondent will get in the Scale $(201 \times 20)$. 
Journal DOI: 10.46654/ij.24889849

\section{Validity and Reliability of the Instruments}

Instruments used in this study based on previous research done in Federal College of Education, Gusau. Zamfara state by Musa (2018), we are using a previously used and tested questionnaire, its validity is already tested. To ensure the reliability, a reliability test cronbach Alpa for Academic Stress Scale (ASC) and Academic Motivation Scale (AMS) are 0.821 and 0.803 respectively.

\section{Procedure for Data Collection}

The administration of the instrument was undertaken by the researcher and the research (3) three assistants. One week was used to administer the questionnaire to UG 2 students, a total of three hundred and twenty two (322) questionnaires were distributed and $100 \%$ retrieved from the respondents and used for data analysis.

\section{Procedure for Data Analysis}

The data collected was analyzed using descriptive and correlation statistics for the purpose of either accepting or rejecting them. Pearson Product Moment Correlation (r) Statistical method was used to test the hypotheses. All the hypotheses were tested at 0.05 alpha levels of significances.

\section{Results}

\section{Hypotheses Testing}

Hypothesis One: There is no significant relationship between academic stress and intrinsic motivation among UG 2 students

\section{Table 2. Pearson Product Moment Correlation on Academic Stress and Intrinsic Motivation of UG 2 Students}

\begin{tabular}{llccccl}
\hline Variables & N & Mean & SD & Df & r & P \\
\hline Academic stress & 322 & 15.8167 & 5.0101 & & & \\
& & & & 320 & 0.706 & 0.012 \\
Intrinsic motivation & 322 & 13.1710 & 3.8111 & & & \\
\hline **. Correlation is significant at & 0.05 level (2-tailed).
\end{tabular}

The result of correlation coefficient in Table 2 revealed that, the p-value of 0.012 is less than the 0.05 alpha levels of significance at a correlation index (r) level of 0.706 . This shows that there is relationship between academic stress and intrinsic motivation. Therefore, the null hypothesis which states that there is no significant relationship between academic stress and intrinsic motivation among UG 2 students of Kebbi state university of science and technology, Aliero is rejected.

Hypothesis Two: There is no significant relationship between Academic stress and extrinsic motivation among UG 2 students 
Table 3. Pearson Moment Correlation on Academic Stress and Extrinsic Motivation of UG 2 Students

\begin{tabular}{lllllll}
\hline Variables & $\mathbf{N}$ & Mean & SD & Df & r & P \\
\hline Academic stress & 322 & 15.8167 & 5.0101 & & & \\
& & & & 320 & 0.623 & 0.003 \\
Extrinsic motivation & 322 & 10.4128 & 3.4109 & & & \\
\hline **. Correlation is significant at 0.05 level (2-tailed). & & &
\end{tabular}

The result of correlation coefficient in Table 3 revealed that, the p-value of 0.003 is less than the 0.05 alpha levels of significance at a correlation index (r) level of 0.632 . This shows that there is relationship between academic stress and intrinsic motivation. Therefore, the null hypothesis which states that there is no significant relationship between academic stress and extrinsic motivation among UG 2 students of Kebbi state university of science and technology, Aliero is rejected.

\section{Discussions}

The purpose of this study is to examine the relationship between academic stress and academic motivation of the UG 2 students of Kebbi state University of Science and Technology, Aliero. This section therefore discusses the findings of the study, in terms of the hypotheses tested in the study. The results revealed that significant relationship exists between academic stress and academic motivation of the UG 2 students of Kebbi state University of Science and Technology Aliero.

This implies that, there is significant relationship between Academic stress and intrinsic/extrinsic motivation. This finding agreed with the study of Felsten and Wilcox (1992) who found a significant correlation between academic stress and academic success. Also, the analysis of Agolla and Ongori (2007) on the correlation between stress and academic achievement of undergraduate students reported that stresses negatively affect students' academic achievement. They further reported that students complained of feeling stressed academically when it comes to facing examination and grade competition and having too much information to study and insufficient time to master the knowledge. Bennett (2003) reported a similar finding that stress is significantly correlated with poor academic performance in his study of business undergraduate students. By implication, as the level of stress increases on undergraduate students the academic performance decreases. It is also supported by Jangho (2012) who noted that Academic stress may be influenced by an interaction among motivation, school grades, depression and personality. Therefore, strategies to reduce academic stress should take into consideration the importance of those factors. Increasing motivation may occur through interventions against stress and depression (Musa 2018).

\section{Conclusion}

Based on the findings of the study, it was concluded that relationship exist between Academic stress and intrinsic motivation, relationship exist between Academic stress and extrinsic motivation among UG 2 students of Kebbi state university of science and technology, Aliero 
Journal DOI: 10.46654/ij.24889849

Article DOI: 10.46654/ij.24889849.a61221

\section{Recommendations}

The following recommendations were made based on the findings of this study:

1. Seminars, workshops and conferences should be organized for all stakeholders in educational sector to know that academic stress is hazardous to the wellbeing of the students; therefore, university should review its policies, goals and objectives to meet the needs and aspirations of students in order to minimize their academic stress.

2. Teachers, parents and counselors should educate students on how to cope with academic stress and understand the adverse effect of academic stress.

\section{Acknowledgments}

This paper became a reality through the support and advice from many people during the implementation of the study. A great appreciation and special thanks to the admission department and students for providing unlimited data for the study 


\section{References}

Abdulraheem, B.O. (2013). Sociological Factors to Drug Abuse and the Effects on Secondary School Student Academic Performance in Ekiti and Ondo States, Nigeria. Contemporary Issues in Education Research, 6(2), 233-240.

Allensworth, E., \& Easton, J.Q. (2007). What matters for staying on-track and graduating Chicago Public High Schools: A close look at course grades, failures and attendance in the freshman year. Chicago: Consortium on Chicago School Research.

Altback, S. (2007). Academic achievement, academic self-concept, and academic motivation of American. Educational Research Journal, 2(3), 129-149.

Agolla, J. E. \& Ongori H, 2007. "An Assessment of Academic Stress among Undergraduate Students: The Case of University of Botswana", Educational Research and Review, 4(2), 63-70

Bennett, R. (2003). Determinants of Undergraduate Students Drop out Rates in a university business students department, Journal of further and High Education, 27(2), 123-141.

Craigmitchell, M. T. (2008). Stress and Depressive Symptoms/ Dysphoria among US Medical during the Preclinical Years. Teaching and Learning in Medicine. 1(1), 125 134.

Felsten, G \& Wilcox, T. (1992). Influences of Stress and Situation-Specific Mastery Beliefs and Satisfaction with Social Support On Well Being and Academic Performance. Psychological Reports 70(1), 291-303.

Gall, T. L., Evans, D. R., \& Bellerose, S. (2000). Transition to First-Year University: Patterns of change in adjustment across life domains and time. Journal of Social and Clinical Psychology, 19(4), 544-567.

Hashin, D. (2003). Intrinsic versus extrinsic motivation: an approach avoidance reformulation. http://www.naturalnews.com/045145-stress-disease-immune-system.

Imbo, I.; Vancevitch, K. M. (2005). The Role of Working Memory in Carrying and Barrowing immigrant adolescents in Greater Toronto Area (GTA) secondary schools (Unpublished master's thesis). Queen's University, Kingston, Canada.

Jangho, G. (2012). Evaluating the use of exploratory factor analysis in psychological research. Retrieved on $27^{\text {th }}$ june, 2020.

Krejcie, R.V. \& Morgan, D. W. (1970). Determining Sample size for research activities in educational and psychological measurements. 607-610. New York: McGraw-Hill.

McMilla, J. H. Schumcher (2010). Education Research; Fundamentals for the consumer $\left(6^{\text {th }}\right.$ Edition). 
Journal DOI: 10.46654/ij.24889849

Article DOI: 10.46654/ij.24889849.a61221

Misra R., McKean S. West \& Russo T. (2000). "Academic Stress of College Students: Comparison of Student and Faculty Perceptions", College Student Journal, 34(2), 236246.

Musa B. G, (2018). Relationship between Psychological Stress and Academic Motivation among Students of Federal College of Education (Technical), Gusau, Zamfara State, Unpublished Master's thesis Submitted to the Department of Educational Psychology and Counselling, Faculty of Education, Ahmadu Bello University, Zaria Nigeria. 